\title{
PENGAMBILAN KEPUTUSAN DENGAN TEKNIK SOFT COMPUTING
}

\author{
Nopi Ramsari, Zen Munawar \\ Universitas Nurtanio, Politeknik LP3I Bandung \\ Jl. Pajajaran No. 219 Lanud Husein Sastranegara Bandung, Jl. Pahlawan No. 59 Bandung \\ nopiramsarihatta2014@yahoo.com, munawarzen@gmail.com
}

\begin{abstract}
Abstrak
Soft Computing adalah sebuah metode yang baik untuk melakukan pengolahan data. Teknik soft computing telah membawa kemampuan otomatisasi ke aplikasi tingkat baru. pengendalian proses adalah sebuah aplikasi penting dari industri apapun untuk mengendalikan parameter sistem yang kompleks, dengan pengendalian paramater dapat memberikan added value dari kemajuan tersebut. Pada pengendalian konvensional umumnya berdasarkan pada model matematika yang menggambarkan perilaku dinamis dari sistem pengendalian proses. Pada pengendalian konvensional terdapat kekurangan yang dapat dipahami, pengendali konvensional sering kalah dengan pengendali (controllers) cerdas. Teknik soft computing memberikan kemampuan untuk membuat keputusan dan belajar dari data yang dapat diandalkan. Selain itu, teknik soft computing dapat mengatasi dengan berbagai lingkungan dan stabilitas ketidakpastian. Makalah ini membahas berbagai bagian teknik soft computing yaitu. fuzzy logic, algoritma genetika dan hibridisasi dan meringkas hasil kasus pengendalian proses. Hasil kesimpulan diperoleh pengendali soft computing memberikan kontrol yang lebih baik pada kesalahan dibandingkan pengendali konvensional. Selanjutnya, pengendali algoritma genetika hibrida berhasil dioptimalkan.
\end{abstract}

Kata kunci :

Fuzzy logic, Algoritma Evolusioner, Algoritma Genetika, Turbin Compressor System

\begin{abstract}
Soft Computing is a good method to perform data processing. Soft computing techniques have brought automation capabilities to a new level applications. process control is an important application of any industry to control the parameters of complex systems, the control parameters can
\end{abstract}

provide the added value of such advances. In the conventional control is generally based on a mathematical model that describes the dynamic behavior of the process control system. In the conventional control there are deficiencies that can be understood, conventional controllers are often inferior to the controller intelligent. Soft computing techniques provide the ability to make decisions and learn from reliable data. In addition, soft computing techniques can cope with different environments and stability of uncertainty. This paper discusses the various parts of soft computing techniques viz. fuzzy logic, genetic algorithms and hybridization and summarizes the results of a case control process. The conclusion obtained by controlling soft computing provides better control on the error compared to conventional controllers. Furthermore, genetic algorithms hybrid controllers successfully optimized.

Keywords:

Fuzzy Logic, Evolutionary Algorithms, Genetic Algorithms, Turbine Compressor System.

\section{Pendahuluan}

Pertumbuhan yang cepat dalam teknologi soft computing telah ditandai sebagai perkembangan baru seperti, pemodelan paradigma dan optimasi mekanisme untuk memecahkan Masalah kontroler yang modern. soft computing telah memberikan metodologi canggih untuk pengembangan industri pengendali proses. Hal ini dianggap sebagai pendekatan seni untuk kecerdasan buatan. Dengan adanya kinerja daya komputasi yang tinggi, perancangan telah diterapkan pada teknik intelijen buatan untuk spektrum yang luas dari masalah di dunia nyata yang cerdas dan pengendalian otonom. Dalam satu dekade terakhir, terlihat perkembangan aplikasi teknik soft computing di bidang teknik. Seperti penggunaan teknik ini dalam berbagai aplikasi teknik yaitu membuat alat yang sangat 
diperlukan. Unsur-unsur pokok pada soft computing seperti teori neuron, fuzzy logic, evolusi komputasi, algoritma genetika, chaostic sistem dan penalaran probabilistik. Terdapat dua teknik yang muncul yaitu logika fuzzy dan algoritma genetika dapat digunakan dalam penelitian ini untuk mengontrol proses sistem.

Dalam beberapa tahun terakhir teknik soft computing yang berdasarkan sistem fuzzy telah dikembangkan untuk solusi kontrol masalah. Alasannya adalah bahwa banyak masalah kontrol dunia nyata hampir tidak bisa dipecahkan dengan teknik konvensional karena informasi yang dibutuhkan tidak tersedia atau sistem yang dipertimbangkan tidak baik. Prinsipnya soft computing adalah memanfaatkan toleransi terhadap ketidaktepatan ketidakpastian parsial kebenaran dan pendekatan untuk mencapai ketahanan solusi biaya rendah dan hubungan yang lebih baik dengan kenyataan (Zadeh LA., 1997). Dalam arti soft computing ini meniru kemampuan manusia tertentu. Namun dalam penerapannya teknik soft computing hasilnya harus divalidasi dengan hati-hati

Teknik soft computing mampu menangani nonlinearitas dan menawarkan kesederhanaan komputasi. Logika fuzzy adalah approximator universal fungsi multivariat karena dapat digunakan untuk pemodelan yang non-linear, pengendali tidak diketahui atau sebagian diketahui. Logika fuzzy membantu seorang insinyur untuk memecahkan masalah pengendalian non-linear dalam proses pengendalian. Dengan mengemulasi penalaran manusia dan menyediakan cara intuitif untuk merancang blok fungsional untuk sistem kontrol cerdas.

Algoritma genetika adalah pencarian heuristik yang meniru proses evolusi alami, dan dapat diterapkan untuk pengendali optimasi proses karena menggunakan operator alami yaitu. mutasi dan crossover (Chang \& Ramakrishna, 2002). Berdasarkan kajian pustaka teknik soft computing dapat mengintegrasikan untuk model sinergis atau hybrid dengan yang hasil yang lebih baik. Simulasi adalah realisasi model komputasi. Simulasi memungkinkan seorang insinyur untuk mengetahui bagaimana model berperilaku untuk variasi parameter tertentu.Simulasi dapat dilakukan untuk merancang dan pelaksanaan pengendalian konvensional proporsional derivatif integral atau proportional integral derivative (PID), fuzzy logic controller (FLC) dan pengendali hybrid fuzzy logic genetic algorithms (Helga). aplikasi simulasi dapat secara dinamis menyesuaikan berbagai parameter kontrol proses.

\section{KAJIAN LITERATUR}

\section{II.1 Logika Fuzzy}

Logika fuzzy mencoba untuk secara sistematis dan matematis meniru nalar manusia dalam membuat keputusan (Toufouti , 2006), dan menyediakan cara intuitif untuk menerapkan pengendalian sistem, pengambilan keputusan dan sistem diagnostik di berbagai cabang industri. Logika fuzzy merupakan konsep yang sangat baik untuk menutup kesenjangan antara akal manusia dan logika komputasi. Terdapat variabel seperti kecerdasan, kredibilitas, kepercayaan dan reputasi. Variabel tersebut tidak bisa direpresentasikan sebagai nilai-nilai, namun estimasi diperlukan, sistem fuzzy adalah teknologi dengan target aplikasi industri dan menambahkan dimensi baru serta menjanjikan domain yang ada dari sistem pengendalian konvensional. Logika fuzzy memungkinkan para insinyur untuk mengeksploitasi mereka pengetahuan empiris dan heuristik yang diwakili dalam aturan IF-THEN dan mentransfernya ke blok fungsional. Sistem logika fuzzy dapat digunakan untuk aplikasi teknik canggih seperti pengendalian sistem cerdas, proses diagnostik, deteksi kesalahan, dan pengambilan keputusan.

\section{II.2 Algoritma Genetika}

Algoritma evolusioner yang berbasis populasi algoritma optimasi meta heuristik yang menggunakan mekanisme biologi yang terinspirasi dan survival pengujian teori untuk memperbaiki solusi iteratif (Yakhchali \& Ghodsypour, 2008). Algoritma genetika merupakan subclass dari algoritma evolusioner di mana unsur-unsur dari ruang pencarian berupa string biner atau array dari tipe dasar lainnya. Algoritma genetika adalah teknik pencarian berbasis komputer berpola mekanisme genetik organisme biologis yang telah beradaptasi dan berkembang dalam mengubah lingkungan yang sangat kompetitif. Saat ini telah banyak kemajuan yang menarik dalam penggunaan algoritma genetika untuk menyelesaikan masalah optimasi dalam sistem kontrol proses. Algoritma genetika adalah solusi untuk optimasi dari masalah sulit yang cepat, akurat dan handal.

\section{II.3 Pengendali Konvensional}

Hal penting dalam pengendalian industri modern adalah dapat mengembangkan metodologi, konsep, 
algoritma, teknologi untuk desain sistem kontrol proses yang harus mampu berkembang, mengembangkan diri, mengorganisir diri, mandiri mengevaluasi dan untuk diri meningkatkan (Adams \& Rattan, 2001). Selama bertahun-tahun, pengendalian proses dan sistem dalam industri ini umum dilakukan oleh para ahli melalui pengendali konvensional proporsional derivatif integral karena kesederhanaan, desain biaya rendah dan kinerja yang kuat dalam kondisi operasional yang luas. sistem kontrol konvensional Berbagai teknologi dan modifikasi telah digunakan untuk mengatasi kesulitan-kesulitan yang ada, termasuk pengendali auto tuning derivatif proporsional, teknik adaptif dan teknik kompensasi. Prosedur pencarian otomatis yang diperlukan untuk pengendali parameter. Konsep teknik cerdas dibuat sebagai sinergi antara sistem konvensional, sistem fuzzy dan algoritma genetika sebagai struktur untuk penyajian informasi dan metode real time sebagai machine learning. Metodologi Soft computing telah terbukti sangat cocok untuk menangani ketidakpastian signifikan yang mungkin dihadapi dalam menyelesaikan masalah dunia nyata.

\section{II.4 Pengendali Fuzzy Logic}

Kapasitas pengendali konvensional berkurang secara signifikan bila diterapkan pada sistem dengan nonlinearities. sistem fuzzy dapat meningkatkan pengendali kinerja konvensional proporsional derivatif integral. Beberapa pendekatan telah diusulkan dan menerapkan sistem kontrol fuzzy untuk mengendalikan proses. Tujuan dari menggabungkan teknik fuzzy dalam sistem kontrol proses dari batasbatas teknik konvensional dan untuk meningkatkan alat yang ada dengan mengoptimalkan kinerja dinamis. Fuzzy kontrol adalah pendekatan fleksibel dan efektif untuk menangani non-linear dan sistem yang pasti. Sebuah pengendali fuzzy proses dapat dilakukan oleh fuzzification, inferensi fuzzy dan defuzzifikasi komponen seperti pada gambar 1 .

Sebuah sistem kontrol fuzzy khas yang terdiri plant dari sensor data yang diterapkan untuk konversi analog ke digital diikuti oleh fuzzy ke konversi teratur yang lebih baik dibandingkan mesin inferensi. Di sisi lain, fuzzy untuk fuzzy konversi teratur diikuti oleh konversi digital ke analog, yang diterapkan sebagai input untuk mengontrol plant dengan cara fuzzy. Proses ini ditunjukkan pada gambar 2 .

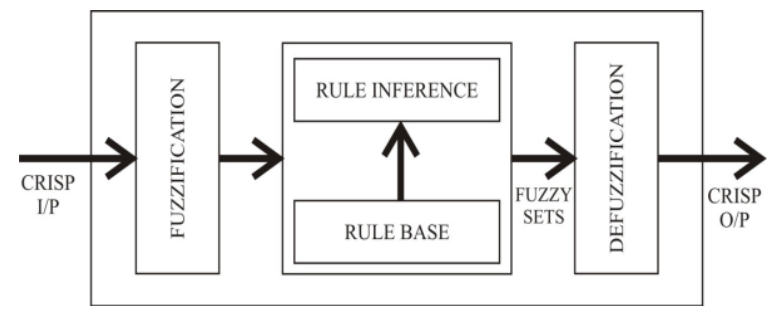

Gambar 1. Schematic of fuzzy logic control.

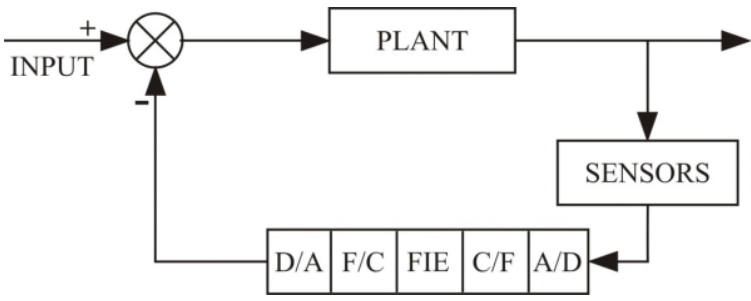

D/A: Digital to Analog conversion

A/D: Analog to digital conversion C/F: Crisp to fuzzy F/C: Fuzzy to Crisp

FIE: Fuzzy Inference Engine

Gambar 2. Systematic fuzzy process control system.

Dasar dari setiap kontroler fuzzy adalah mesin inferensi, yang terdiri dari seperangkat aturan yang mencerminkan basis pengetahuan dan struktur penalaran untuk solusi dari masalah. metode kontrol fuzzy sangat penting untuk memenuhi tuntutan sistem non linear kompleks karena memberikan kuat, adaptif, karakter diri untuk sistem yang kompleks yang menuntut stabilitas dan fungsionalitas tinggi di luar kemampuan dari metode tradisional. sistem fuzzy dan teori kontrol fuzzy telah menambahkan dimensi baru untuk mengontrol sistem rekayasa. Sebuah logika fuzzy dapat menghasilkan non-linear hukum kontrol sewenang-wenang dan kurangnya prosedur yang sistematis untuk konfigurasi parameter masih menjadi kendala utama dalam aplikasi praktis. Desain kontroler logika fuzzy telah dikendalikan dengan algoritma genetika untuk lebih mengoptimalkan parameter kontroler.

\section{II.5 Pengendali Algoritma Genetika}

Algoritma genetika yang dimodelkan pada strategi evolusi alami adalah metodologi yang telah diperkenalkan dan teknik optimasi untuk memecahkan masalah yang kompleks. Selanjutnya, algoritma genetika mencari memiliki paralelisme 
yang melekat yang memungkinkan identifikasi cepat dari daerah kinerja domain tinggi yang kompleks tanpa mengalami masalah dengan dimensi tinggi.

Teori algoritma genetika didasarkan pada inisialisasi kromosom, memberikan nilai fitness kromosom yang sesuai dengan kriteria kinerja mereka, reproduksi berdasarkan probabilitas crossover yang membagi kode biner dari setiap orang tua menjadi dua atau lebih segmen dan kemudian menggabungkan ke memberikan keturunan baru yang telah mewarisi bagian dari coding nya dari setiap orangtua, proses mutasi di mana coding dari keturunan dilakukan dengan probabilitas rendah. algoritma optimasi ini melakukan pencarian stokastik dengan iterasi dari populasi solusi sesuai dengan kebugaran mereka. Dalam pengendalian aplikasi, fitnes terkait dengan ukuran kinerja dari pengendali proses. Kinerja pengendali logika fuzzy dapat ditingkatkan jika model penalaran fuzzy dilengkapi dengan mekanisme algoritma genetika. Algoritma genetika memungkinkan kita untuk menghasilkan set optimal parameter untuk model logika fuzzy.

Sebuah Algoritma genetika (Goldberg, D.E, 1989) dimulai dengan tebakan dan upaya untuk meningkatkan tebakan oleh evolusi. Algoritma genetika biasanya akan memiliki lima bagian:

1. Representasi dari menebak disebut kromosom,

2. Suatu pool awal kromosom,

3. Fungsi fitness,

4. Fungsi seleksi dan

5. Crossover operator dan operator mutasi. Sebuah kromosom dapat berupa string biner atau lebih rumit struktur data. Kumpulan awal kromosom dapat dihasilkan secara acak atau secara manual dibuat.

Untuk memenuhi ditentukan fungsi fitness mengukur kesesuaian kromosom

Tujuan: untuk ATG cakupan berdasarkan, kromosom adalah fit jika itu sesuai dengan yang lebih besar cakupan. Fungsi seleksi yang memutuskan kromosom akan berpartisipasi dalam evolusi tahap algoritma genetika dibuat oleh crossover dan mutasi operator.

Crossover operator pertukaran gen dari dua kromosom dan menciptakan dua kromosom baru. Operator mutasi perubahan gen dalam kromosom dan menciptakan yang kromosom baru.
Algoritma genetika memiliki langkah-langkah yang terdefinisi dengan baik:

Sebuah algoritma dasar untuk Algoritma genetika adalah sebagai berikut (Somerville, I.,2004)

Pseudo kode untuk Algoritma genetika adalah:

Initialize (population)

Evaluate (population)

do

While (stopping condition not satisfied)

\{

Selection (population)

Crossover (population)

Mutate (population)

\}

Evaluate (population)

Algoritma akan iterate sampai populasi k telah berkembang untuk membentuk solusi untuk masalah ini, atau sampai jumlah maksimum iterasi telah terjadi (menunjukkan bahwa solusi tidak akan ditemukan diberikan sumber daya yang tersedia).

\section{II.6 Hibridasi dari Teknik Soft Computing}

Hibridisasi sistem cerdas adalah bidang yang menjanjikan kecerdasan modern untuk pengembangan kontroler generasi berikutnya. Integrasi teknik soft computing dapat memecahkan masalah sulit dalam industri kontrol proses. Teknik kecerdasan buatan Hybrid menyediakan pemecahan masalah model yang lebih kuat dan dapat diandalkan dibandingkan model standalone. mengintegrasikan ini teknik meningkatkan kekuatan keseluruhan dan mengurangi kelemahan sehingga membantu untuk memecahkan keseluruhan Masalah kontrol dengan cara yang efektif. Berbagai strategi, model dan desain telah diusulkan oleh peneliti untuk mengintegrasikan berbagai sistem cerdas untuk aplikasi praktis.

Tujuan akhir dari integrasi adalah untuk memodelkan masalah dengan mengambil keuntungan dari kekuatan untuk mencapai efektivitas dan efisiensi. Model matematika dapat digunakan dalam hubungannya dengan teknik cerdas untuk meningkatkan kinerja sistem hybrid untuk aplikasi dunia nyata. Aplikasi baru untuk masalah dunia nyata dari sistem hybrid yang terintegrasi bertujuan untuk mencapai hasil yang lebih baik Hasil dari teknik mandiri. Sistem fuzzy dengan kemampuan belajar dan adaptasi, komputasi evolusioner telah memunculkan fuzzy sistem hybrid genetik dengan kemampuan adaptasi algoritma evolusioner. 
Fuzzy sistem telah menunjukkan kemampuan untuk menunjukkan alasan perkiraan khas manusia dengan cara komputasi yang efisien. Aalgoritma genetika, di sisi lain, merupakan teknik yang kuat dalam kompleksitas masalah optimasi, identifikasi, pembelajaran dan adaptasi. Juga meningkatkan kemampuan untuk desain dan optimasi sistem fuzzy. Tujuan utama dari kecerdasan buatan adalah untuk menghasilkan mesin cerdas yang mensimulasikan dan meniru kecerdasan manusia.

Parameter dari sistem fuzzy ditentukan oleh perancang. Algoritma genetika telah diusulkan sebagai metode pembelajaran yang dapat mengaktifkan generasi otomatis parameter optimal untuk pengendali fuzzy, berdasarkan beberapa kriteria objektif. algoritma genetika dapat diterapkan dengan kabur dalam tiga cara. Algoritma genetika adalah suatu pendekatan yang efisien dan kuat untuk menghasilkan aturan fuzzy. Integrasi teori logika.

Fuzzy dengan algoritma genetika memiliki dua fungsi. Algoritma genetik digunakan untuk mengoptimalkan parameter fuzzy logic dan kedua logika fuzzy secara otomatis mengubah parameter genetik seperti mutasi, tingkat Crossover selama proses optimasi. Algoritma untuk melakukan algoritma genetika logika fuzzy regresi dapat di lihat pada gambar 3 .

Sebagai bidang studi baru Algoritma Hybrid pada computational intelligence telah memperoleh perhatian luas dari banyak sarjana. Di berbagai bidang penelitian dan aplikasi, semakin banyak cabang computational intelligence telah membuat kemajuan besar, telah menjadi subjek penelitian yang populer.

Metode computational intelligence, meskipun berbeda satu sama lain, berbagi properti menjadi nonsimbolis dan beroperasi secara bottom-up, di mana struktur muncul dari unordered mulai dan berbeda dari metode yang dikenakan dalam kecerdasan buatan (Esmaeili V., 2008).

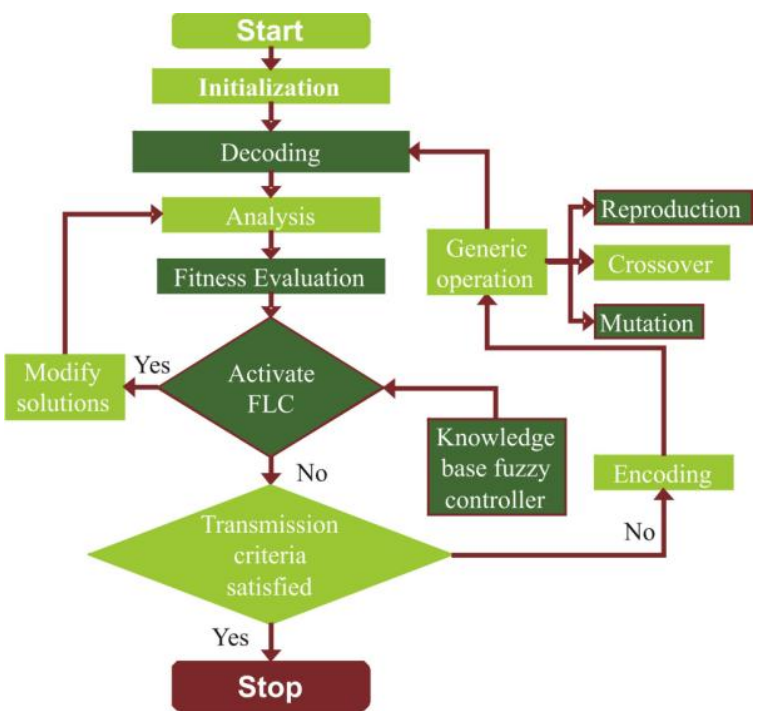

Gambar 3. Blok diagram dari hybrid fuzzy logic genetic algorithm.

Computational intelligence terutama mengadopsi ideologi connectionism dan benar-benar menggunakan ide-ide bionik untuk referensi, itu asalusul dari meniru fenomena cerdas di alam dan digambarkan dalam bahasa matematika. kecerdasan komputasi mencoba untuk mensimulasikan dan munculnya kembali karakter kecerdasan sehingga dapat menjadi domain penelitian baru untuk merekonstruksi alam dan rekayasa. Bezdek menganggap bahwa kecerdasan Komputasi didasarkan pada data yang disediakan oleh operator daripada mengandalkan "pengetahuan", yang memecahkan masalah melalui pembentukan koneksi dengan pelatihan.

Prof. Lotfi A. Zadeh (Zeng Hui, LI Yuanxiang, (2010), mengusulkan pendekatan baru untuk machine intelligence; memisahkan teknik hard computing berdasarkan artificial intelligence dari teknik soft computing lunak berbasis computational intelligence (Gambar 4).

Hard computing berorientasi analisis dan desain proses fisik dan sistem, dan memiliki karakteristik presisi, formalitas, categoricity. Hal ini didasarkan pada logika biner, crisp system, analisis numerik, teori probabilitas, persamaan diferensial, analisis fungsional, pemrograman matematika, dan pendekatan teori dan crisp software. Gambar 5: artificial intelligence vs computational intelligence. Soft computing berorientasi analisis dan desain sistem cerdas. 


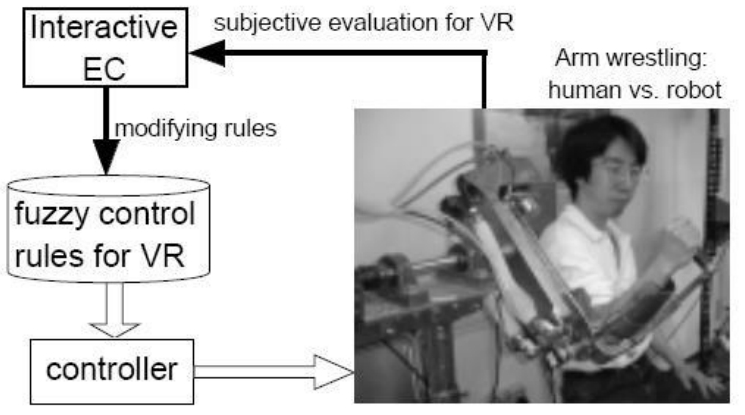

Gambar 4. Virtual reality of arm wrestling. Fuzzy logic controller evolve based on human perception of Virtual reality. (Marcos Gestal Pose, 2010)

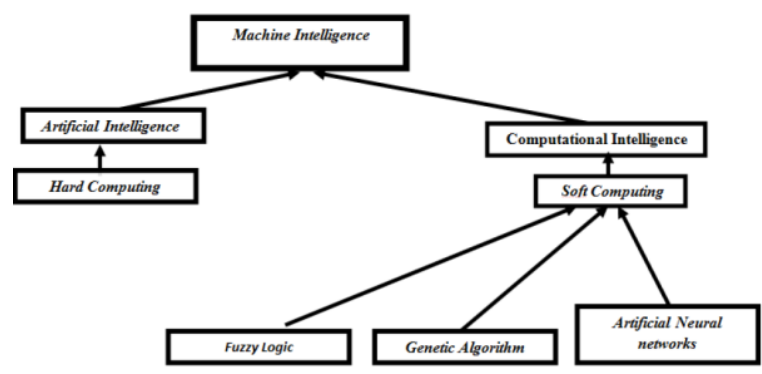

Gambar 5. Artificial Intelligence vs. Computational Intelligence

Meskipun dalam hard computing ketidaktepatan dan ketidakpastian adalah properti yang tidak diinginkan, dalam komputasi lembut toleransi terhadap ketidaktepatan dan ketidakpastian dimanfaatkan untuk mencapai solusi yang dapat diterima dengan biaya rendah, tractability, tinggi Machine Intelligence Quotient (MIQ). Prof. Zadeh berpendapat bahwa soft computing, daripada komputasi keras, harus dilihat sebagai dasar dari kecerdasan mesin nyata. soft computing, saat ia menjelaskan, adalah konsorsium metodologi menyediakan landasan bagi konsepsi dan desain sistem cerdas, ditujukan pada formalisasi kemampuan manusia yang luar biasa untuk membuat keputusan yang rasional di lingkungan yang tidak pasti dan tidak tepat.

Prinsip dari soft computing adalah: Eksploitasi toleransi terhadap ketidaktepatan, ketidakpastian dan kebenaran parsial untuk mencapai tractability, ketahanan, solusi biaya rendah dan hubungan yang lebih baik dengan kenyataan.

Fuzzy logic (FL) ini terutama berkaitan dengan ketidaktepatan dan penalaran perkiraan, jaringan saraf terutama dengan belajar dan curve fitting, perhitungan evolusioner dengan pencarian dan optimasi.

\section{STUDI KASUS - SISTEM KECEPATAN PADA TURBIN GAS}

Turbin gas termasuk non linier yang memiliki beberapa input dan beberapa output (Balamurugan \& Jeyakumar, 2009). Karena untuk rotasi dan tinggi suhu tinggi dari turbin gas, parameter operasional harus sering di rawat dan disetel. Sistem kontrol kecepatan turbin berdasarkan pengendalian dengan teknik kecerdasan buatan. Turbin gas sering ditemui di kilang dalam bentuk turbin uap yang menggunakan hidrolik untuk mengontrol kecepatan turbin (Merrington, 1993). Sebuah proporsional konvensional derivatif dapat digunakan untuk mengontrol sistem turbin kompresor. Dalam hal ini adalah sebuah sistem kontrol umpan balik yang mengukur variabel output dan mengirimkan sinyal kontrol ke kontroler. Controller membandingkan nilai sinyal output dengan nilai referensi dan memberikan sinyal kontrol untuk elemen kontrol akhir melalui aktuator. Ziegler-Nichols (Z-N) metode bergantung pada loop terbuka respon langkah atau tes respon frekuensi loop tertutup. Sebuah proporsional derivatif integral disetel sesuai dengan tabel berdasarkan respon proses uji. Menurut Zeigler-Nichols kriteria tala respon frekuensi $0,6 \mathrm{p} \mathrm{cu} \mathrm{K}=\mathrm{K}, 0,5 \mathrm{i} \mathrm{t}=\mathrm{T}$ dan $0,125 \mathrm{~d} \mathrm{t}=\mathrm{T}$.

Untuk proporsional integral derivatif dalam studi kasus ini, nilai-nilai tuning parameter yang diperoleh adalah $\mathrm{Kp}=18, ? \mathrm{i}=1,4, ? \mathrm{~d}=0,3$ dan $\mathrm{P}=30, \mathrm{I}=$ $21,4, \quad \mathrm{D}=9$. Biasanya, nilai-nilai desain awal derivatif integral (PID) proporsional yang diperoleh oleh semua berarti perlu disesuaikan berulang kali melalui simulasi komputer sampai sistem loop tertutup melakukan atau kompromi seperti yang diinginkan. Perhitungan dilakukan di Simulink. Proporsional integral derivatif memberikan overshoot dari 52,4\%, settling time dan puncak waktu 9,66 detik dan 10,9 detik masing-masing, yang cukup tinggi dan akan menghasilkan distorsi tinggi dalam sistem. Karena respon yang tinggi di pengendali proporsional integral derivatif, Hasilnya menyimpang dan efisiensi pabrik jauh berkurang (Nagraj \& Rampriya, 2008). Fuzzy proporsional derivatif integral (PID) pengendali adalah perpanjangan alami dari konvensional mereka versi, yang melestarikan 
struktur linier mereka derivatif integral. Fuzzy proporsional integral derivatif controller dirancang menggunakan prinsip fuzzy logic control untuk mendapatkan controller baru yang memiliki formula analitis sangat mirip dengan proporsional integral derivatif digital. Dalam studi eksperimental ini, interpretasi klasik dari operasi logika Mamdani diterapkan. Fuzzy logic controller (FLC) memberikan overshoot jauh lebih rendah, waktu penyelesaian dan waktu puncak daripada konvensional proportional integral derivatif (PID). nilai khas overshoot adalah $8.75 \%$ dan menetap waktu dan puncak waktu yang 6,8 detik dan 6,2 detik masing-masing, yang menunjukkan perbandingan perbaikan dalam kontroler fuzzy berdasarkan logika daripada konvensional proportional integral derivatif (PID) untuk parameter kontrol proses yang berbeda. algoritma genetika adalah teknik optimasi cerdas (Chang Wook Ahn \& Ramakrishna, 2002) yang mengandalkan paralelisme ditemukan di alam, khususnya prosedur pencarian yang yang didasarkan pada mekanisme seleksi alam dan genetika. algoritma genetika, dengan ukuran populasi 20 kromosom, jalankan untuk 50 generasi. Metode roda Roulette digunakan untuk seleksi kromosom, dengan dua titik Crossover, memiliki probabilitas mutasi 0.01 . Tanggapan langkah fuzzy algoritma genetika sistem hybrid menunjukkan bahwa transien parameter respon yang lebih baik dioptimalkan dari fuzzy logic controller (FLC) dan konvensional proportional integral derivatif (PID). Hal ini menunjukkan keunggulan algoritma genetika hybrid fuzzy lebih sebagai pengendali konvensional dan pengendali fuzzy mandiri.

Untuk memverifikasi hasil Simulink model berbasis sistem turbin kompresor menggunakan blok optimum set, m-file juga dihasilkan menggunakan perintah MATLAB. Melalui analisis komparatif flow control dari sistem turbin kompresor, hybrid fuzzy genetic algoritma (HFLGA) menunjukkan overshoot hampir diabaikan dari sekitar $1 \%$ dan peningkatan yang luar biasa dalam waktu penyelesaian dan puncak waktu yang nilai-nilai khas adalah sekitar 3,7 detik dan 4,1 detik masing-masing. Perbandingan kinerja kesalahan parameter yang tidak terpisahkan dari integral of absolut error (IAE) dan integral of time and absolut error (IAE) dari proporsional integral derivatif (PID), fuzzy logic controller (FLC) dan hybrid fuzzy genetic algoritma (HLFGA) controler menunjukkan superioritas kontroler hybrid stand alone dan proporsional integral derivatif (PID) controller. Integral and absolut error (IAE) dan Integral of time and absolut error (ITAE) dari proporsional integral derivatif (PID) adalah 0,98 dan 1,94 masing-masing. Integral of absolut error (IAE) dan tidak terpisahkan dari Integral of time and absolut error (ITAE) dari fuzzy logic controller (FLC) adalah 0,83 dan 0,91 masing-masing. Integral of absolut error (IAE) dan tidak terpisahkan dari Integral of time and absolut error (ITAE) dari hybrid fuzzy genetic algoritma (HLFGA) controller 0,76 dan 0,98 , yang sangat kurang dan menunjukkan kontrol dioptimalkan kontroler hybrid pada kesalahan dari turbin gas.

\section{STUdi KaSUS -Pengendalian TORSI LANGSUNG DARI MOTOR INDUKSI}

Pertama-tama, teknik kecerdasan buatan yang dimasukkan untuk mengatasi kelemahan yang melekat skema kontrol torsi langsung konvensional, seperti masalah awal dari negara-negara null, kebutuhan torsi dan estimator fluks (Kumar K., Sakthibala D. dan Palaniswami S.,2010). Dalam metode kontrol torsi langsung konvensional, tegangan diterapkan untuk seluruh periode, yang pada gilirannya menghasilkan arus stator tinggi dan torsi elektromagnetik dengan hasil riak torsi tinggi yang dihasilkan selama operasi bermotor (Pujar J.H dan S.F. Kodad, 2009).

Teknik cerdas untuk menganalisis kinerja tinggi dipisahkan fluks dan kontrol torsi memiliki dilaksanakan dalam pekerjaan ini. logika fuzzy digunakan untuk memilih negara inverter untuk mencapai torsi dan nilai-nilai referensi fluks. Untuk eksperimen, 3-fase, 1-kilowatt, $1300 \mathrm{rpm}$ induksi drive motor diambil. fungsi keanggotaan segitiga digunakan untuk mewakili kesalahan fluks, kesalahan torsi elektromagnetik dan sudut fluks. aturan fuzzy yang dihasilkan oleh metode trial and error untuk pemilihan negara inverter yang tepat. Sebuah motor dikenakan frekuensi $10 \mathrm{KHz}$, pengambilan sampel waktu $0,1 \mathrm{~ms}$, dan memiliki torsi dan referensi fluks nilai 2,5 $\mathrm{Nm}$ dan $0,5 \mathrm{~Wb}$ masing-masing.

Algoritma genetika telah diterapkan untuk 150 generasi memiliki ukuran populasi 20 kromosom. 50\% dari tingkat crossover dan $10 \%$ dari laju mutasi dengan crossover titik tunggal digunakan selama simulasi. Metode Roulette pilihan roda dengan nilai-nilai fitness dinormalisasi digunakan untuk seleksi kromosom. Studi simulasi 
menunjukkan peningkatan maksimum $23 \%$ di fluks kesalahan untuk logika fuzzy dan hybrid logika fuzzy algoritma genetika kontroler. untuk operasi kondisi a $=100 \%, \mathrm{~b}=100 \%$, fluks kesalahan $2.5 \mathrm{e}-3$ dan $1,8 \mathrm{e}-$ 3 telah dicatat untuk logika fuzzy controller dan hybrid logika fuzzy algoritma genetika kontroler masing-masing. Studi simulasi dilakukan pada kondisi operasi yang berbeda dari motor. Hal ini disimpulkan dari simulasi hasil bahwa peningkatan kesalahan fluks di logika fuzzy mandiri dan logika fuzzy hybrid genetik kontroler algoritma adalah 23\%, $22 \%, 19 \%, 18 \%$ dan $17 \%$ untuk kondisi operasi a $=$ $100 \%, \mathrm{~b}=100 \%$.

Selanjutnya, untuk kondisi operasi $\mathrm{a}=50 \%, \mathrm{~b}=$ $50 \%$, peningkatan kinerja di fluks kesalahan berkisar dari $10 \%$ menjadi $2 \%$ untuk logika mandiri dan logika fuzzy algoritma genetika hybrid pengendali masing-masing.

Untuk kondisi operasi di atas, persentase peningkatan kesalahan torsi juga telah mencatat. Untuk kondisi operasi $\mathrm{a}=100 \%, \mathrm{~b}=100 \%$, kinerja peningkatan sekitar 3\% dicatat dalam logika fuzzy mandiri dan logika fuzzy hybrid genetik kontroler algoritma. Untuk kondisi operasi yang berbeda peningkatan kinerja dicatat. Saya simpulkan dari hasil simulasi di atas bahwa peningkatan kinerja dalam kesalahan fluks dan error torsi lebih pada kecepatan awal motor. Singkatnya, logika fuzzy controller berdasarkan genetik teknik algoritma melebihi kontroler logika mandiri fuzzy.

\section{Studi Kasus -Perbandingan Metode TRADISIONAL DAN SOFT COMPUTING DI Aplikasi Pengendalian WaKtu NYATA}

Dalam contoh aplikasi ini, bola harus dipindahkan sembarang melalui labirin yang yang dipasang di papan. Gerak bola dicapai dengan menggunakan dua motor langkah. Sebuah kamera video dipasang di atas papan untuk mengamati efek dari gerakan papan. Pada pandangan pertama masalah mungkin muncul, tapi mirip atau terkait masalah (misalnya gerak atau masalah keseimbangan) muncul dalam banyak aplikasi industri. Gambar. 4 menunjukkan komponen perangkat keras (kiri) dan fotografi (kanan). Masalah keseluruhan diselesaikan dalam dua langkah berikutnya. Pada langkah pertama (pre-processing) itu perlu untuk mendeteksi posisi bola dan dan cara melalui labirin.

Hasilnya adalah jalur dari awal ke titik target labirin berbentuk poligonal a. Langkah kedua adalah tahap real-time yang bertanggung jawab untuk menavigasi bola sepanjang jalan dengan mendekati titik sudut dari satu poligonal demi satu. Awalnya, koordinat baru dari pusat bola diperkirakan dengan mempertimbangkan beberapa posisi masa lalu dari ball.Then, pusat tepat terlokalisir di daerah ("jendela geser") sekitar estimasi pusat menggunakan mis metode pas prototipe (Keidl M, Kickingereder R, 1997). Posisi saat bola dan posisi titik target berikutnya (sudut poligonal) digunakan untuk menghitung urutan motor langkah. Ada berbagai kemungkinan untuk menangani tugas ini.
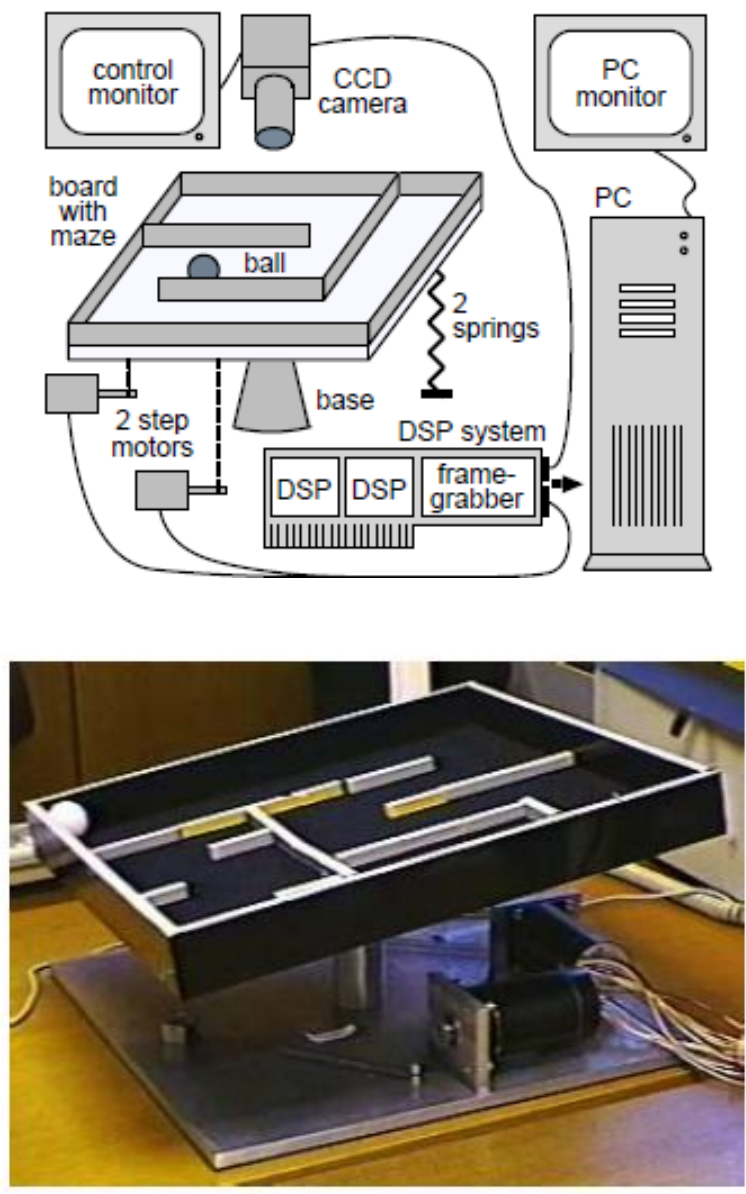

Gambar 4. Peralatan perangkat keras dari contoh aplikasi

Agar diperoleh hasil yang bisa mewakili semua data pada pengendali, maka setiap tes telah diulang 
dua puluh kali dan mean dan standar deviasi dari kriteria peringkat berikut telah ditentukan.

1. Jarak yang ditempuh bola (diukur dalam pixel);

2. Menjalankan waktu antara awal (start point) dan akhir (titik sasaran terakhir) gerak (diukur dalam detik)

3. Rata-rata deviasi (diukur dalam pixel)

4. Maks. penyimpangan bola (diukur dalam pixel)

5. Rata-rata jumlah siklus prosesor per perhitungan

6. Jumlah langkah bermotor

Jalan melalui labirin telah keras-kode untuk menjamin persis jalan yang sama untuk setiap tes dan, karena itu, hasil yang sebanding. Ini "referensi jalan" memiliki panjang 1.139 piksel. Hasil untuk jaringan dilatih secara online akan ditampilkan setelah waktu tertentu pelatihan online (dengan pelatihan online jumlah siklus prosesor adalah sekitar 67000)

Tabel 1. Hasil Percobaan (Keidl)

\begin{tabular}{lllllllllll}
\hline \hline Paradigm & \multicolumn{2}{l}{ Fuzzy } & \multicolumn{3}{l}{ Pre-trained } & \multicolumn{2}{l}{ Online } & \multicolumn{2}{l}{ Conv. } \\
& \multicolumn{2}{l}{ controller } & & \multicolumn{3}{c}{ trained NN } & \multicolumn{2}{l}{ Controller } \\
& $\mu$ & $\sigma$ & $\mu$ & $\sigma$ & $\mu$ & $\sigma$ & $\mu$ & $\sigma$ \\
\hline \hline Distance & 1478 & 26,3 & 1459 & 27,7 & $\mathbf{1 4 1 0}$ & 31,7 & 1560 & 24,0 \\
Run time & 70,2 & 1,21 & 66,7 & 1,24 & $\mathbf{5 2 , 9}$ & 0,88 & 59,4 & 1,02 \\
Avg. dev. & 2,50 & 0,21 & $\mathbf{1 , 8 8}$ & 0,16 & 3,47 & 0,19 & 3,24 & 0,22 \\
Max. dev. & 12,1 & 1,40 & $\mathbf{1 0 , 4}$ & 1,89 & 13,9 & 1,36 & 16,6 & 4,02 \\
Cycles & 3669 & 0,73 & 10992 & 0,07 & 10911 & 0,06 & $\mathbf{4 6 5}$ & 5,31 \\
Mot. Steps & 12316 & 177 & 11244 & 134 & $\mathbf{9 0 4 8}$ & 193 & 9520 & 284 \\
\hline \hline
\end{tabular}

Hal ini dapat dilihat, bahwa pre-trained jaringan saraf (yang membutuhkan fungsi transfer dari kontroler fuzzy untuk pelatihan) adalah yang terbaik untuk menavigasi bola dekat dengan jalan yang diberikan (berarti deviasi rata-rata 1,88 piksel, berarti deviasi maksimum 10,4 piksel). Jaringan dilatih secara online panduan bola sangat cepat melalui labirin (berarti menjalankan waktu 52,9 detik) dan, oleh karena itu, rata-rata ditutupi jarak terpendek (1410 piksel). Selain itu, controler ini membutuhkan langkah jumlah bermotor terkecil (9048). Pada akhirnya, controller konvensional memiliki algoritma kontrol yang sangat cepat (berarti jumlah siklus prosesor sebesar 465).

\section{KESIMPULAN}

Hasil analisis stabilitas logika fuzzy dan algoritma genetika berdasarkan pengendali nonlinear. Percobaan pada non-linear dan kontrol kontrol kecepatan kompresor turbin yang khas sistem untuk mengendalikan keluaran gas dilakukan dengan menggunakan strategi logika fuzzy dan teknik hybrid fuzzy logic algoritma genetika. Bila dibandingkan dengan kontroler konvensional, logika fuzzy memberikan kontrol yang lebih baik pada kesalahan sementara dan penggabungan genetik algoritma dengan logika fuzzy akan lebih mengoptimalkan parameter kontroler. Fuzzy logic dan teknik hybrid fuzzy logic algoritma genetika mengungguli pendekatan konvensional dalam hal minimalisasi kesalahan. Untuk menilai jenis kontroler yang berbeda, masing-masing kontroler telah diuji menggunakan labirin yang sama dan jalan yang sama. Untuk membandingkan pengendali secara adil, setiap tes telah diulang dua puluh kali dan mean dan standar deviasi dari kriteria Peringkat berikut telah ditentukan

Hal ini terbukti dari hasil studi kasus diambil dalam makalah ini bahwa teknik soft computing dalam penelitian ini dapat mengatasi proses yang kompleks non-linear pengendalian sistem. Dapat ditarik kesimpulan bahwa logika fuzzy adalah sebuah pendekatan sistematis untuk mengendalikan proses. Selain fuzzy logic, hibridisasi dengan algoritma genetik, akan lebih memberikan optimasi yang lebih baik.

\section{REFERENSI}

Adams J. M. and Rattan K. S., (2001), "Genetic multi-stage Fuzzy PID controller with a Fuzzy switch", IEEE Transactions on Systems, Man, and Cybernetics, Vol. 4, pp.2239-2244.

Balamurugan S., Xavier R. and Jeyakumar A., (2009) , "Control of Heavy-duty Gas Turbine Plants for Parallel Operation Using Soft Computing Techniques", Electric Power Components and Systems, 37(11), pp.1275 1287.

Chang Wook Ahn and Ramakrishna, R.S., (2002), “A genetic algorithm for shortest path routing problem and the sizing of populations," 
IEEE Transactions on Evolutionary Computation, 6(6), pp. 566-579.

Esmaeili V., Assareh A., Shamsollahi M.B. Maoradi M.H. and Arefian N.M. (2008), "Estimating thedepth of anesthesia using fuzzy soft computation applied to EEG features," Intelligent data Analysis,12, pp. 393-407.

Goldberg, D.E, , (1989), "Genetic Algorithms: in Search, Optimization \& Machine Learning," Addison Wesley, MA.

Keidl M, Kickingereder R., Maydl M, Ramsauer M, Schichl G, Seltzsam S, Volgelhuber V.,",(1997), Praktikum im Vertiefungsgebiet Technische Anwendungen der InformatikDokumentation. technical report, “, University of Passau.

Kumar K., Sakthibala D. and Palaniswami S., (2010), "Efficiency optimization of Induction Motor Drive using Soft computational techniques," International Journal of Computer Applications, 3(1), pp. 6-12.

Marcos Gestal Pose, and Daniel Rivero Cebrián (2010), "Soft Computing Methods for Practical Environment Solutions: Techniques and Studies" Release Date: May, University of A Coruna, Spain.

Merrington, G. L., (1993), "Fault Diagnosis in Gas Turbines Using a Model Based Technique," American Society of Mechanical Engineers, ASME Paper.

Nagraj B., Subha S. and Rampriya B., (2008), "Tuning Algorithm for PID controller using soft computing Techniques," International Journal of Computer Science and network Security, 8(4), pp. 278-281.

Pujar J.H and S.F. Kodad, "DigitalSimulation of Direct Torque Fuzy of Control PMSM Servo System", International Journal of Recent Trends in Engineering, 2(2), pp. 89.93, 2009.

Somerville, I., (2004), Software Engineering, 7th Ed. Addison-Wesley.

Toufouti R. Meziane S., (2006), "Direct torque control for Induction Motor using Fuzzy Logic,"ACSE Journal, 6(2), pp. 19-26.
Yakhchali S. H. and Ghodsypour S. H.,(2008), "A Hybrid Genetic Algorithms for Computing the Float of an Activity in Networks with Imprecise Durations", Proceedings of the IEEE International Conference on Fuzzy Systems ,FUZZ-2008, pp.1789-1794.

Zadeh LA. (1997), "What is soft computing?.", in: Soft Computing,vol. 1 no. 1, 1997.

Zeng Hui, LI Yuanxiang, (2010), "Optimization of Fuzzy Controller Based on Dynamic Evolutionary Algorithm ", International Conference on Intelligent Computing and Cognitive Informatics. 